\title{
Cytogenetic study in natural hybrids of Callithrix (Callitrichidae: Primates) in the Atlantic forest of the state of Rio de Janeiro, Brazil.
}

\author{
Denise M. Nogueira ${ }^{1}$, Ana Maria R. Ferreira ${ }^{2}$, Beatriz Goldschmidt ${ }^{3}$, Alcides Pissinatti ${ }^{4}$ \\ Juliane B. Carelli ${ }^{5} \&$ Carlos E. Verona ${ }^{6}$
}

\begin{abstract}
1. Departamento de Genética, Instituto de Biologia, Universidade Federal Rural do Rio de Janeiro/UFRRJ, Rodovia BR-465, km 7, 23890-000 Seropédica, RJ, Brasil. (denisemn@ufrrj.com) 2. Departamento de Patologia e Clínica Veterinária, Faculdade de Veterinária, Universidade Federal Fluminense/UFF, Rua Vital Brazil Filho, 64, 24230-340 Niterói, RJ, Brasil. (anaferreira@pesquisador.cnpq.br) 3. Serviço de Criação de Primatas, Centro de Criação de Animais de Laboratório, Fundação Oswaldo Cruz (CECAL/FIOCRUZ), Av. Brasil 4365, 21040-900 Rio de Janeiro, RJ, Brasil. (bibi@fiocruz.br) 4. Centro de Primatologia do Rio de Janeiro, CPRJ/INEA, Estrada do Paraíso, s/n, 25940-000 Guapimirim, RJ, Brasil. (pissinatticpri@globo.com) . Médica Veterinária Autônoma. (julianecarelli@gmail.com)

6. Universidade Estácio de Sá (UNESA), Estrada Borda do Mato, 850, 22783-320 Vargem Pequena, RJ, Brasil. (carlos.verona@ensp.fiocruz.br)
\end{abstract}

\begin{abstract}
In the Atlantic forest of Rio de Janeiro, Callithrix aurita (É. Geoffroy in Humboldt, 1812) is a native species vulnerable to extinction and C. jacchus (Linnaeus, 1758) and C. penicillata (É. Geoffroy, 1812) are invasive species. The major threats to the native species are habitat degradation and hybridization, although there are currently no genetic data about natural hybrids available. Previous studies have revealed that species of the Callithrix genus are extremely homogeneous in their karyotypes with the exceptions of the morphology and size of the Y chromosome and its nucleolar organizer region (NOR) banding pattern. Three male marmosets captured in the wild in Guapimirim municipality, Rio de Janeiro, Brazil, considered as possible hybrids between C. aurita and C. jacchus or C. penicillata on the basis of pelage pattern, were cytogenetically studied. Metaphase chromosomes were obtained by using short-term lymphocyte cultures and Ag-NOR staining was performed. The hybrids karyotypes were $2 \mathrm{n}=46,14$ uni- and 30 bi-armed autosomes, a median size submetacentric $\mathrm{X}$ and NOR bearing autosomes, being compatible with that observed for the genus. In the three individuals studied, $Y$ chromosomes were similar to those found for $C$. aurita, without NORs. The data obtained suggest the involvement of $C$. aurita in natural hybridization with one of the invasive species. We discuss the possible consequences of this hybridization.
\end{abstract}

KEYWORDS. Marmosets, Y-chromosome, karyotype, hybridization.

RESUMO. Estudo citogenético em híbridos naturais de Callithrix (Callitrichidae: Primatas) na Mata Atlântica do Estado do Rio de Janeiro, Brasil. No estado do Rio de Janeiro, em área de Mata Atlântica, Callithrix aurita (É. Geoffroy in Humboldt, 1812) é a espécie nativa considerada vulnerável à extinção e C. jacchus (Linnaeus, 1758) e C. penicillata (É. Geoffroy, 1812) são espécies invasoras. As principais ameaças à espécie nativa são a degradação do habitat e a hibridação, embora não haja, até o momento, dados genéticos que confirmem a hibridação natural. Estudos anteriores revelaram que as espécies do gênero Callithrix são extremamente homogêneas em seus cariótipos, diferindo quanto à morfologia do cromossomo $\mathrm{Y}$ e padrão de marcação da região organizadora de nucléolo (NOR). No presente estudo, três saguis machos capturados na natureza no município de Guapimirim, distrito de Teresópolis, RJ, considerados como possíveis híbridos entre $C$. aurita e $C$. jacchus ou C. penicillata, com base no padrão de pelagem, foram estudados citogeneticamente. Os cromossomos metafásicos foram obtidos pela técnica de cultura de linfócitos e a coloração Ag-NOR foi realizada. Os cariótipos dos híbridos, 2 n=46, continham 14 autossomos com um braço e 30 com dois braços, um cromossomo X de tamanho médio submetacêntrico e marcação NOR nos autossomos, sendo compatíveis com aquele observado para o gênero. Nos três casos, o cromossomo Y foi similar ao observado em C. aurita, sem marcação NOR. Os dados obtidos sugerem a participação de C. aurita em hibridação natural com as espécies invasoras e suas prováveis consequências são discutidas.

PALAVRAS-CHAVE. Saguis, cromossomo y, cariótipo, híbridicação.

The South American primate genus Callithrix Erxleben, 1777 belongs to the family Callithrichidae, which occurs in the Atlantic forest and neighboring Caatinga and Cerrado biomes of central and northeastern Brazil (Sena et al., 2002). The genus comprises six parapatric taxa that originally occupied areas of ecological transition (VERACINI et al., 2002): Callithix jacchus (Linnaeus, 1758), C. penicillata (É. Geoffroy, 1812), C. geoffroyi (Humboldt, 1812), C. flaviceps (Thomas, 1903), C. aurita (É. Geoffroy in Humboldt, 1812) and C. kuhli (Coimbra-Filho, 1985) (MitTermeIER et al., 1992; RYLANDS et al., 1993; RoOSMALEN et al., 1998).

The common marmoset $C$. jacchus originally inhabited dry thorn scrub (Caatinga) and nearby regions of Atlantic forest in northeastern Brazil (MitTERMEIER et al., 1988; RYlands et al., 1993), south to the state of Bahia. For at least one century it was introduced in other regions of the Atlantic forest, particularly in southeastern Brazil, establishing itself in areas occupied by other
Callithrix species (Coimbra-Filho, 1990; Brandão \& Develley, 1998; Ruiz-Miranda et al., 2000).

Callithrix penicillata occurs in seasonal environments of gallery forests, forest patches and savanna (Cerrado) in central Brazil (HershKovitz, 1977). This species, as in the previous case, is invading and possibly replacing other species in many regions of the east and south, in the states of Minas Gerais, Espírito Santo, São Paulo and Rio de Janeiro (Rylands et al., 1993; Rосна et al., 2004). The other four species occur in the Atlantic forest of eastern and southeastern Brazil: C. kuhli and C. geoffroyi inhabit lowlands while $C$. aurita and C. flaviceps occur in the mountainous rain forests above $400-500 \mathrm{~m}$.

Typical of the Atlantic forest of Rio de Janeiro, $C$. aurita also occurs in the east and northeast of São Paulo and in the southern part of Minas Gerais (CormbraFilho, 1986; BRandẽo \& Develley, 1998). This species is considered vulnerable, according to the International 
Union for Conservation of Nature (IUCN, 2008), and is also listed in the Convention on International Trade in Endangered Species (CITES, 2009) and in the Brazilian Institute for the Environment's list of nationally threatened species (IBAMA, 2003), due to its small population size and ongoing decline. The widespread degradation of the Atlantic forest and the hybridization with invasive species (C. jacchus and $C$. penicillata) are the major threats to $C$. aurita, although the extent of the latter remains obscure (RYLANDS et al., 2009). Coimbra-Filno et al. (1993) reported the occurrence of experimental hybridization in captivity among Callithrix species which resulted in fertile individuals with several distinct phenotypes. There is also evidence of natural hybridizations at the distributional limits of the Callithrix species or due to introduction (in the case of C. jacchus and C. penicillata) (Rylands et al., 2000). The present study examines three male Callithrix captured in the wild in Guapimirim municipality, state of Rio de Janeiro, Brazil, which were considered possible hybrids between C. aurita and C. jacchus or $C$. penicillata according to indistinct pelage.

Many invasive species take opportunistic advantage of other forms of ecosystem change, such as habitat disturbance, rather than being the direct cause of the decline of native species (DiDHAm et al., 2005). For the establishment of conservation management plans to protect the vulnerable species, different causal mechanisms that lead to interspecific breeding must be distinguished. The genetic confirmation of the hybridization is imperative to clarify if there is a directional pattern in the hybridization and also in the survival and reproduction of the hybrids.

From the cytogenetic aspect, the Callithrix species represent a homogeneous clade with the exceptions of morphology and size of the $\mathrm{Y}$ chromosome, and their Ag-NOR pattern (NAgAmachi \& FerRari, 1984; Ardito et al., 1987).

Based on chromosomal differences already reported for Callithrix species, our objectives were: to analyze the morphology of the $\mathrm{Y}$ chromosome of the three possible hybrids, comparing its morphology with that previously observed for C. aurita, C. jacchus and C. penicillata; to identify the paternal species involved in hybridization; and to examine if the $\mathrm{Y}$ chromosome of the individuals studied present secondary constriction similar to that reported for C. jacchus, which would indicate paternity by a male of this species.

\section{MATERIAL AND METHODS}

Three male marmosets considered as possible hybrids between Callithrix aurita and C. jacchus or $C$. penicillata on the basis of pelage pattern were cytogenetically studied. The individuals were captured in the wild in Guapimirim $\left(22^{\circ} 32^{\prime} 14^{\prime \prime} \mathrm{S}, 42^{\circ} 58^{\prime} 55^{\prime \prime} \mathrm{W}\right)$, in the state of Rio de Janeiro at an altitude of $40 \mathrm{~m}$, in the forest near the Rio de Janeiro Primate Centre (CPRJ/ INEA), Brazil, where these species are kept in captivity. The capture location is part of the Atlantic forest, a highly threatened ecosystem, classified as a global hotspot of biodiversity due to its exceptional concentration of endemic species and the loss of more than $70 \%$ of its primary vegetation (MYERs et al., 2000).

Metaphase chromosomes were obtained by using the lymphocyte culture method (MOORHEAD et al., 1960). Blood $(2 \mathrm{~mL})$ was collected at CPRJ/INEA by femoral puncture in heparinized syringes. Chromosomes were analyzed by conventional staining with $3 \%$ Giemsa in phosphate buffer $\mathrm{pH} 6.8$ and examined at a 100x magnification. Nucleolar organizing region (NOR) characterization was performed following Howell \& BLACK (1980). The karyotypes of the three possible hybrids were compared to those previously described by Nagamachi (1995) and Nagamachi et al. (1997) (Fig. 1).

\section{RESULTS}

The karyotypes of the three possible hybrid marmosets showed the same pattern observed in the genus Callithrix. They presented $2 \mathrm{n}=46$, with 14 uni- and 30 bi-armed autosomal pairs, a median submetacentric $\mathrm{X}$ and a diminutive uni-armed $\mathrm{Y}$ chromosome, similar to that found in C. aurita (Fig. 2).

The Ag-NOR staining marked secondary constrictions located in the short arms of six acrocentric autosomes (Fig. 3). Active NOR was not found on the Y chromosome differing from that observed in C. jacchus (Bedard et al., 1978; Nagamachi \& Ferrari, 1984; ARDITO et al., 1987).

\section{DISCUSSION}

The five Callitrix species, except $C$. flaviceps (not studied), present $2 \mathrm{n}=46,14$ acrocentric and 30 bi-armed autosomes, a median size submetracentric $\mathrm{X}$ chromosome, and differ only in the morphology of the Y chromosome (Fig. 1; NAGAMACHI et al., 1997), which in the case of $C$. jacchus was variable even between populations. The $\mathrm{Y}$ chromosome is subtelocentric in individuals from Bahia and metacentric in those from Pernambuco, probably due to a pericentric inversion (NAGAMachi \& FerRari, 1984).

Analysis of the G- and C-banding patterns demonstrated a lack of any chromosomal rearrangements to differentiate their karyotypes (NAGAMACHI et al., 1997).

Ag-NOR staining marked secondary constrictions of the small arms of the acrocentric chromosomes of all Callithrix species studied. Callithrix jacchus differs from its congeners by being the only species that shows Ag-NOR staining on the Y chromosome (BEDARD et al., 1978; NAgAMACHI \& FerRaRi, 1986; Ardito et al., 1987).

The karyotype of the three individuals studied 


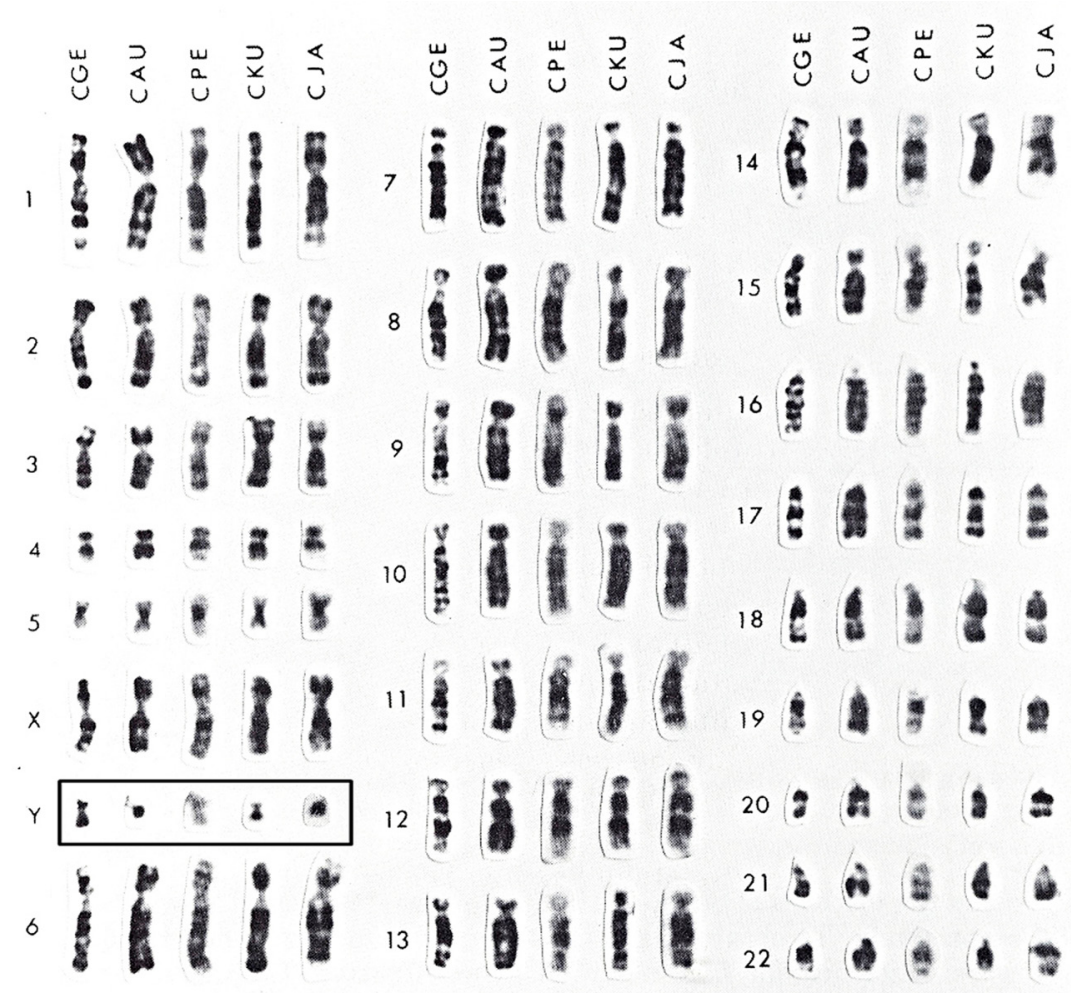

Fig. 1. Comparison of G-banding pattern of the five Callithrix species according to NAGAMACHI et al. (1997): CGE, C. geoffroyi; CAU, C. aurita; CPE, C. penicillata; CKU, C. kuhlii; CJA, C. jacchus. The black box emphasizes the morphology of the Y chromosomes of the five species.
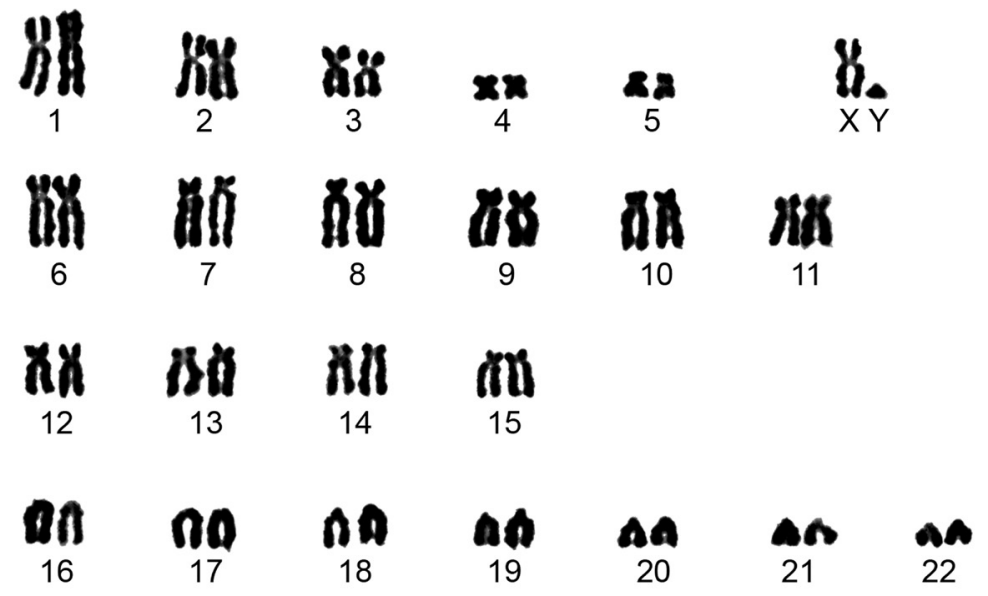

Fig. 2. Karyotypic pattern found in all Callithrix hybrids with $2 \mathrm{n}=46, \mathrm{XY}$ and the diminutive $\mathrm{Y}$ chromosome similar to $C$. aurita as described by NAGAMACHI et al. (1997).

was compatible with that described for the genus. The $\mathrm{Y}$ chromosome similar to that of $C$. aurita and the absence of NOR in this chromosome suggest that the paternal species of the three possible hybrids is $C$. aurita, and that one of the invaders, $C$. jacchus or $C$. penicillata, is the maternal species.

Cytogenetic and molecular analyses conducted so far indicate that the Callithrix genus constitute a homogeneous clade with little genetic divergence among the species, which suggests that the speciation in this group is recent (SCHNeIDER, 2000) and that they can still be in a process of speciation (VERACINI et al., 2002).

One piece of evidence of the close phylogenetic relation of the taxa is the fact that all species hybridize at the distributional limits of the various forms $(C$. penicillata x C. geoffroyi, C. penicillata x C.kuhlii, C. geoffroyi $\times$ C. flaviceps, C. aurita x C. flaviceps) or due to the introduction of one (or both) forms (C. jacchus and C. penicillata) (Coimbra-Filho et al., 1993). In the last case, the occurrence of those species together with 


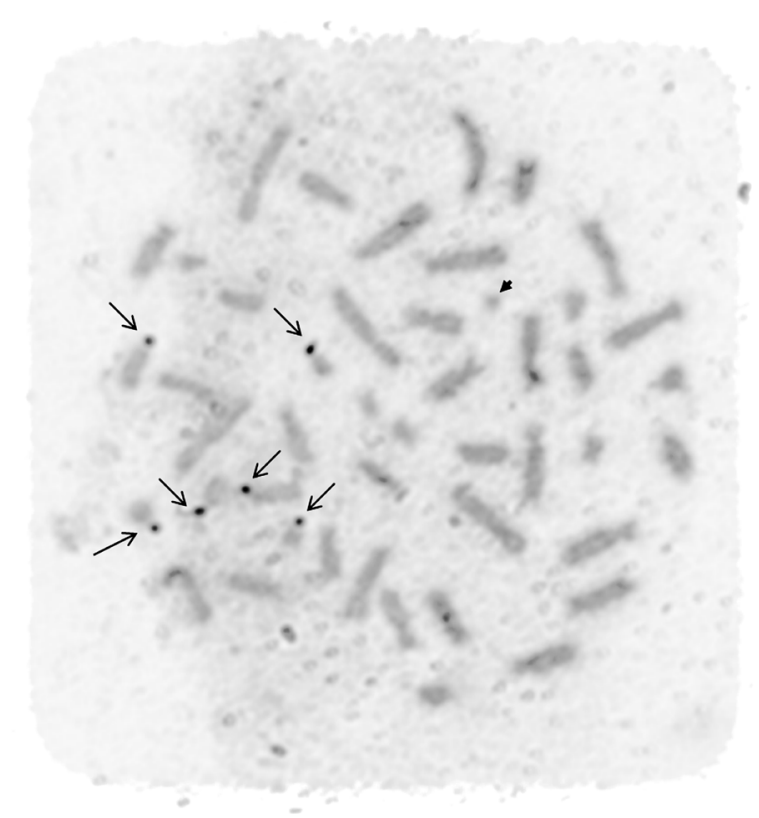

Fig. 3. Ag-NOR stained metaphase of Callithrix sp. All the hybrids have similar NOR banding pattern. The arrows indicate six NORbands in the short arms of acrocentric chromosomes. The head of the arrow indicates the diminutive $\mathrm{Y}$ chromosome without NOR.

C. aurita allied with its population decline can result in interspecific breeding and generation of natural hybrids.

Since the only karyotypic difference among the species is represented by the $\mathrm{Y}$ chromosome morphology, it does not interfere with synapse during the meiosis, allowing for the production of normal gametes. The great genetic similarity contributes to the viability and fertility of the hybrid descendents observed in captivity (CoImBra-Filho, 1978); however, its fitness in the wild in terms of survival and reproductive success has yet to be determined.

Although there are few studies on the breeding and social behavior of $C$. aurita, polygyny was observed as a mating system for one group studied in São Paulo, southeastern Brazil (Coutinho \& CorrêA, 1995). Due to the population decline, hybridization can be viewed in the case of the threatened species as an alternative strategy to carry on reproduction. Otherwise, by "hybrid vigor", the hybrids can represent an additional competitor to the vulnerable species, possibly superior to the invasive species, C. jacchus and C. penicillata, which have already established themselves in the new territory.

Biological invasion is now considered to be one of the "big five" environmental issues of public concern (SALA et al., 2000), since a significant emphasis has been placed on invasive species as one of the leading causes of species decline and loss of biodiversity (WILCOVE et al., 1998; VітоUSEK et al., 1996). The data presented here represents the first attempt to confirm the involvement of $C$. aurita in interspecific breeding, although further genetic analyses are necessary to identify the other species involved and the magnitude of the involvement.
When management strategies to control biological invasion are being debated, including invasive species eradication (ZAVALETA et al., 2001), genetic analysis can help understand the type and the extension of interactions between native and invasive species to direct conservation action in order to accomplish effective restoration goals.

Acknowledgements. We thank Fundação de Amparo à Pesquisa do Estado do Rio de Janeiro/FAPERJ for providing a Pos-Doc scholarship to DMN and a research grant for AP (Proc. E-26/171.271/2006). AP thanks Financiadora de Estudos e Projetos (FINEP). We also thank Conselho Nacional de Desenvolvimento Científico e Tecnológico (CNPq), which provided an undergraduated scholarship for JBC, and also the Instituto Brasileiro do Meio Ambiente e Recursos Naturais Renováveis/IBAMA for the capture license, Fundação RIOZOO for providing Callithrix jacchus blood samples, CPRJ/INEA for providing scientific material and for the maintenance in captivity of the Callithrix individuals captured in the wild, Laboratório de Ecologia da ENSP/FIOCRUZ and Laboratório de Análises Clínicas Laborlife for the support to CEV. We would like to thank Dr Cristiani G. Iughetti and an anonymous referee for helpful comments on the paper.

\section{REFERENCES}

Ardito, G.; Lamberti, L.; Bigatti, P.; Stanyon, R. \& Govone, D. 1987. NOR distribution and satellite association in Callithrix jacchus Caryologia 40:185-194.

Bedard, M. T.; Ma, N. S. F. \& Jones, T. C. 1978. Chromosome banding patterns and Nucleolar Organizing Regions in three species of Callithrichidae (Saguinus oedipus, Saguinus fuscicollis and Callithrix jacchus). Journal of Medical Primatology 7:82-87.

Brandẽo, L. D. \& Develley, P. F. 1998. Distribution and conservation of the Buffy Tufted-Ear marmoset, Callithrix aurita, in lowland coastal Atlantic forest, Southeast Brazil. Neotropical Primates 6:86-88.

CITES (Convention on International Trade in Endangered Species of Wild Fauna and Flora). 2009. Appendices I, II, and III to Convention on International Trade in Endangered Species of Wild Fauna and Flora. Arlington, U.S. Fish \& Wildlife Service. 12p.

Coimbra-Filho, A. F. 1978. Sobre um caso de triplo-hibridismo em Callithrix (Callithrichidae, Primates). Revista Brasileira de Biologia 38:61-67.

1986. Sagui-da-serra-escuro Callithrix aurita (É. Geoffroyi, 1812). FBCN/Informativo do Rio de Janeiro 10:3.

1990. Sistemática, distribuição geográfica e situação atual dos símios brasileiros (Platyrrhini-Primates). Revista Brasileira de Biologia 50:1063-1079.

Coimbra-Filho, A. F.; Pissinatti, A. \& Rylands, A. B. 1993. Experimental multiple hybridism among Callithrix species from eastern Brazil. In: Rylands, A. B. ed. Marmosets and tamarins: systematics, ecology and behavior. Oxford, Oxford University Press. p.95-120.

Coutinho, P. E. G. \& CorrêA, H. K. M. 1995. Polygyny in a free ranging group of buffy-tufted-ear Marmosets, Callithrix aurita. Folia Primatologica 65:25-29.

Didham, R. K.; Tylianakis, J. M.; Hutchison, M. A.; Ewers, R. M. \& Gemmel, J. 2005. Are invasive species the drivers of ecological change? Trends in Ecology and Evolution 20:470-474.

Hershrovitz, P. 1977. Living New World monkeys (Platyrrhini), v.1. Chicago, University of Chicago Press, $1132 \mathrm{p}$.

Howell, W. M. \& Black, D. A. 1980. Controlled silver staining of Nucleolar Organizing Regions with protective colloidal developer: a 1-step method. Experientia 36:1014.

IBAMA (Instituto Brasileiro do Meio Ambiente e dos Recursos Naturais Renováveis). 2003. Lista das espécies da fauna brasileira ameaçadas de extinção. Brasília, Ministério do Meio Ambiente, IBAMA. Available at: <http://www.biodiversitas.org. br>. Accessed on 30 August 2009. 
IUCN (International Union for Conservation of Nature and Natural Resources). 2008 IUCN Red List of threatened species. Available at: $<\mathrm{http}: / /$ www.iucnredlist.org $>$. Accessed on 30 August 2009.

Mittermeier, R. A.; Rylands, A. B. \& Coimbra-Filho, A. F. 1988. Systematics: species and subspecies - an update. In: MitTERMEIER; R. A.; Rylands, A. B.; Coimbra-Filho, A. F. \& Fonseca G. A. B. eds. Ecology and behavior of Neotropical primates. v.2. Washington, World Wildlife Fund. p.13-75.

Mittermeier, R. A; Schwarz, M. \& Ayres, J. M. 1992. A new species of marmoset, genus Callithrix Erxleben, 1777 (Callitrichidae, Primates), from the Rio Maués region, state of Amazonas, Central Brazilian Amazonia. Goeldiana Zoologia 14:1-17.

Moorhead, P. S.; Nowell, P. C.; Mellman, W. J.; Battips, D. M. \& Hungerford, D. A. 1960. Chromosomes preparations of leucocytes cultures from human peripheral blood. Experientia Cell Research 20:135-136.

Myers, N.; Mittermeier, R. A.; Mittermeier, C. G.; Fonseca, G. A. B. \& KENT, J. 2000. Biodiversity hotspots for conservation priorities. Nature 403:853-858.

NagamaCHI, C. Y. 1995. Chromosomal relations and phylogenetic and phonetic analyses in the Callithrichidae. Neotropical Primates 3:88-89.

Nagamachi, C. Y \& Ferrari, I. 1984. Cytogenetic studies of Callithrix jacchus (Callitrichidae, Platyrrhini) from two different sites in Brazil. I. Morphological variability of Y chromosome. Revista Brasileira de Genética 7:497-507.

1986. Cytogenetic studies of Callithrix jacchus (Callitrichidae, Platyrrhini) from two different sites in Brazil. II. NOR on the Y chromosome. Mammalian Chromosomes Newsletter 27:81-86.

Nagamachi, C. Y.; Pieczarka, J. C.; Schwarz, M.; Barros, R. M. S. \& MatTEVI, M. S. 1997. Comparative chromosomal study of five taxa of genus Callithrix, group jacchus (Platyrrhini, Primates). American Journal of Primatology 41:53-60.

Rocha, C. F. D.; Bergallo, H. G.; Pombal JR.; Geise, L.; Van Sluys, M.; Fernandes, R. \& Caramaschi, U. 2004. Fauna de anfíbios, répteis e mamíferos do estado do Rio de Janeiro, Sudeste do Brasil. Publicação Avulsa do Museu Nacional 104:3-23.

Roosmalen, M. G. M. Van; Roosmalen, R. A. Van; Mittermeier, R. A. \& Fonseca, G. A. B. 1998. A new and distinctive species of marmoset (Callithrichinae, Primates) from the lower Rio Aripuanã, state of Amazonas, Central Brazilian Amazonia. Goeldiana Zoologia 22:1-23.

Ruiz-Miranda, C. R.; Affonso, A. G.; Martins, A. \& Beck, B. 2000 Distribuição do sagüi (Callithrix jacchus) nas áreas de ocorrência do mico-leão-dourado (Leontopithecus rosalia) no Estado do Rio de Janeiro. Neotropical Primates 8:98-101.
Rylands, A. B.; Coimbra-Filho, A. F. \& Mittermeier, R. A. 1993. Systematics, distributions, and some notes on the conservation status of the Callitrichidae. In: Rylands, A. B. ed. Marmosets and tamarins: systematics, behaviour and ecology. Oxford, Oxford University Press. p.11-77.

Rylands, A. B.; KierulfF, M. C. M.; Mendes. S. L. \& Oliveira, M. M. 2009. Callithrix aurita. In: IUCN. IUCN Red List of Threatened Species. Version 2009.1. Available at: <http: www.iucnredlist. org $>$. Accessed on 1 July 2009.

Rylands, A. B.; Schneider, H.; Langguth, A.; Mittermeier, R. A. Groves, C. \& Rodríguez-LunA, E. 2000. An assessment of the diversity of New World primates. Neotropical Primates 8:61-93.

Sala, O. E.; Chapin, F. S.; Armesto, J. J.; Berlow, E.; Bloomfield, J.; Dirzo, R.; Huber-Sanwald, E.; Huenneke, L. F.; Jackson, R. B.; Kinzig, A.; Leemans, R.; Lodge, D. M.; Mooney, H. A.; Oesterheld, M.; Poff, N. L.; Sykes, M.T.; Walker, B. H.; WALKeR, M. \& WALL, D. H. 2000. Global biodiversity scenarios for the year 2100. Science 287:1770-1774.

SChNeIDER, H. 2000. The current status of the New World monkey phylogeny. Anais da Academia Brasileira de Ciências 72:166172.

Sena, L.; Vallinoto, M.; Sampaio, I.; Schneider, H.; Ferrari, S. F. \& Schneider, M. P. 2002. Mitochondrial COII gene sequences provide new insights into the phylogeny of Marmosets species groups (Callithrichidae, Primates). Folia Primatologica 73:240251.

Veracini, C.; Galleni, L. \& Forti, M. 2002. The concept of species and the foundations of biology, a case study: the Callithrix jacchus Group (Primates-Platyrrhini). Rivista di Biologia/ Biology Forum 95:75-100.

Vitousek, P. M.; D'antonio, C.; Loope, L. L. \& Westbrooks, R. 1996. Biological invasions as global environmental change. American Scientist 84:468-478.

Wilcove, D. S.; Rothstein, D.; Dubow, J.; Phillips, A. \& Losos, E. 1998. Quantifying threats to imperiled species in the United States. Bioscience 48:607-615.

Zavaleta, E. S.; Hobbs, R. J. \& Mooney, H. A. 2001. Viewing invasive species removal in a whole-ecosystem context. Trends in Ecology and Evolution 16:454-459. 